\title{
Milk yield differences between $1 \times$ and $4 \times$ milking are associated with changes in mammary mitochondrial number and milk protein gene expression, but not mammary cell apoptosis or SOCS gene expression
}

\author{
A. P. Alex, ${ }^{* 1}$ J. L. Collier, ${ }^{*}$ D. L. Hadsell, $†$ and R. J. Collier ${ }^{* 2}$ \\ *School of Animal and Comparative Biomedical Sciences, University of Arizona, Tucson 85721 \\ †Departments of Pediatrics and Molecular and Cellular Biology, USDA/ARS Children's Nutrition Research Center, Baylor College of Medicine, \\ Houston, TX 77030
}

\begin{abstract}
Milking frequency is known to affect milk production and lactation persistence in dairy cows. Despite this, the mechanisms underlying this effect are only partially understood. Previous work in dairy cows examining increases in milk yield due to increased milking frequency have identified changes in apoptosis and expression of genes regulating cytokine signaling. In addition, changes in mitochondrial biogenesis and function have been suggested to play a role during the lactation cycle in regulating milk production. The goal of this study was to test the hypothesis that, when maintained over an entire lactation, extreme differences in milking frequency would be reflected in differences in apoptosis, mammary mitochondrial number, and the mammary expression of genes known to inhibit cytokine signaling. Primiparous Holstein cows $(\mathrm{n}=6)$ were assigned to the study $40 \mathrm{~d}$ before parturition after which $1 \mathrm{ud}$ der half was milked once daily $(1 \times)$ and the other 4 times daily $(4 \times)$ Mammary biopsies were collected at $15,60,120$, and $230 \mathrm{~d}$ of lactation. Average milk yield from the $4 \times$ side was 3 times higher than from the $1 \times$ side. Analysis of milk composition revealed that protein, lactose, and solids-not-fat percentages were lower in $1 \times$ than $4 \times$ udder halves. Mammary cell apoptosis was not affected by milking frequency. Mammary cell mitochondrial number, as estimated by succinate dehydrogenase staining, was higher in early lactation, decreasing as days in milk increased, and with increased milking frequency. Although mammary expression of $\alpha$-lactalbumin ( $L A L B A)$ and $\beta$-casein (CSN2) was significantly increased in $4 \times$ glands, the expression of suppressors of cytokine signaling were similar between $1 \times-$ and $4 \times$-milked halves. These results support the conclusion that changes in milk production in response

Received September 30, 2014.

Accepted March 25, 2015.

${ }^{1}$ Current address: 107, 16 Brybeck Crescent, Kitchener, ON, N2M 2C6, Canada.

${ }^{2}$ Corresponding author: rcollier@ag.arizona.edu
\end{abstract}

to extreme differences in milking frequency may be related to alterations in mitochondrial number and lactose synthesis, but not apoptosis.

Key words: lactation, milking frequency, mammary, cow, apoptosis

\section{INTRODUCTION}

In dairy animals, increased milking frequency enhances milk production and lactation persistence (Bauman and Vernon, 1993; Erdman and Varner, 1995) and, in most cases (Bar-Peled et al., 1995; Hale et al., 2003), milk production remained elevated for a period after the milking frequency treatment was terminated. Milk production in dairy cows declines after peak lactation by a phenomenon referred to as secretory diminution (Hadsell et al., 2006). Secretory diminution is associated with increases in mitochondrial oxidative damage within the mammary glands (Hadsell et al., 2006). Recent research by Wall et al. (2005) found that mammary expression of suppressors of cytokine signaling (SOCS) proteins are elevated during prolonged lactation. Changes in milking frequency lead to changes in mammary cell turnover in cattle (Hillerton et al., 1990; Hale et al., 2003). The activity of key enzymes involved in milk synthesis also changes because of changes in milking frequency (Wilde et al., 1987; Travers et al., 1996). Hale et al., (2003) suggested that mammary cell apoptosis can be transiently stimulated after $3 \mathrm{~d}$ of increased milking frequency. The half-udder model is useful in demonstrating the effect of increased milking frequency on milk yield and mammary gene expression (Knight et al., 1990). Cows milked once daily demonstrate a significant loss in milk production (Boutinaud et al., 2003). Several studies have compared the effects of twice versus once daily milking (Harding and Harding, 1990; Auldist and Prosser, 1998; Davis et al., 1999). However, these effects of a more extreme difference in milking frequency, such as once versus four times daily have not been investigated. The goal of our study was to test the hypothesis that, when maintained 
over an entire lactation, extreme differences in milking frequency would be reflected by differences in apoptosis, mammary mitochondrial number compared with cells present, and the mammary expression of genes associated with cellular growth.

\section{MATERIALS AND METHODS}

\section{Animals and Experimental Design}

Study protocol and procedures involving animals were approved and conducted in accordance with the University of Arizona Institutional Animal Care and Use Committee. Six pregnant primiparous dairy cows in good health with no previous history of mastitis were assigned to the study $40 \mathrm{~d}$ before expected calving. Animals were housed at the University of Arizona Dairy (Tucson, AZ) and received close-up rations until they calved and lactating ration after calving according to the management program of the University of Arizona Dairy. The close-up ration was formulated with $65 \%$ $\mathrm{DM}$ and lactating ration with $70 \% \mathrm{DM}$ by weight, with water added to the rations to complete the diet (Table 1). The animals were group housed until they calved. Following calving, the cows were housed in individual pens with access to shade and water and the udder halves of each animal were assigned to once $(\mathbf{1} \times)$ or four times $(4 \times)$ daily milking by coin flipping. The $1 \times$ udder halves were milked at $0400 \mathrm{~h}$ and $4 \times$ udder halves were milked at 0400, 1000, 1600, and $2200 \mathrm{~h}$. Milk volume was recorded at each milking and milk samples were obtained from each udder half once weekly for composition analysis. Each udder half was biopsied on d 15, 60, 120, and 230 of lactation to collect tissue to measure mitochondria and apoptosis.

\section{Milk Composition}

Weekly milk samples were taken, pooled, and analyzed for fat percent, true protein percent, lactose percent, and SCC by Arizona Dairy Herd Improvement Association (Tempe, AZ) using the Bentley 2500 optical system (Bentley Instruments Inc., Chaska, MN). Milk fat, protein, and lactose were analyzed using AOAC-approved infrared analysis and SCC by AOAC-approved cell-staining techniques (AOAC International, 2007). All equipment used in the analyses was certified by the International Dairy Federation and Food and Drug Administration.

\section{Mammary Tissue Sampling}

As udder half was the experimental unit, both udder halves were biopsied at each time point, according to procedures by Farr et al. (1996) with modifications by Baumgard et al. (2000) and Annen et al. (2005). Biopsy sites alternated between front and rear quarters for each half with each biopsy. Biopsied quarters were treated with an intramammary antibiotic (Amoxi-Mast, Pfizer, La Jolla, CA) at the time of surgery and at the first 2 milkings after the biopsy. Penicillin $\left(6 \times 10^{6} \mathrm{IU}\right.$; AgriCillin, AgriLabs, St. Joseph, MO) as a systemic antibiotic was initiated the day before a biopsy and continued until $3 \mathrm{~d}$ following the biopsy. Postsurgery health was monitored by taking rectal temperature twice daily for $4 \mathrm{~d}$ following a biopsy and by continuous evaluation for any fluctuations in milk yield and DMI. Similar to Annen et al. (2005), we demonstrated no adverse effect of multiple biopsies per quarter using this technique. Approximately $250 \mathrm{mg}$ of tissue was isolated from each udder half, flash frozen, and stored in liquid nitrogen for future use.

\section{Mitochondrial Staining}

Mammary biopsy tissues collected on d 15, 60, 120, and 230 of lactation from both $1 \times$ and $4 \times$ sides were cryosectioned at $10 \mu \mathrm{m}$ thickness then stored at $-80^{\circ} \mathrm{C}$ until stained. To visualize mitochondria for counting, the slides were stained for succinate dehydrogenase activity, as previously described (Hadsell et al., 2011), and counter-stained with methyl green. Stained slides were viewed under a phase contrast microscope at $100 \times$

Table 1. Composition of the total mixed diet fed to lactating and close- up dry cows

\begin{tabular}{lcc}
\hline Ingredient, g/kg of DM & Lactating cows $^{1}$ & Close-up cows $^{2}$ \\
\hline Alfalfa hay & 532.9 & 601.6 \\
Almond hulls & 6.23 & - \\
Amino Plus & 16.5 & - \\
Bermuda grass hay & - & 18.2 \\
Corn (steam-flaked) & 163.6 & - \\
Corn distillers grain & 21.8 & 105.6 \\
Dry citrus pulp & 78.6 & - \\
EnerG II & 14.4 & - \\
Fat Bran (155 tallow) & 29.5 & - \\
Molasses (cane) & 40.8 & 34.4 \\
Supplement & & 35.9 \\
Whole cottonseed & 65.0 & 35.0 \\
\hline
\end{tabular}

${ }^{1}$ Diet was $70 \% \mathrm{DM}$ and contained $18 \% \mathrm{CP}, 1.74 \mathrm{Mcal}$ of $\mathrm{NE}_{\mathrm{L}} / \mathrm{kg}$ of DM, 25.2\% ADF, and 40.3\% NDF based upon analysis of the total mixed diet; water added was $30 \%$ by weight.

${ }^{2}$ Diet was $65 \% \mathrm{DM}$ and contained $15.3 \% \mathrm{CP}, 1.63 \mathrm{Mcal} \mathrm{NE} / \mathrm{Lg}$ of $\mathrm{DM}, 43.9 \% \mathrm{ADF}$, and $56.7 \% \mathrm{NDF}$ based upon analysis of the total mixed diet; water added was $35 \%$ by weight.

${ }^{3}$ AminoPlus (Soy Best, West Point, NE); EnerG II (Bioproduct, Fairlawn, $\mathrm{OH})$.

${ }^{4}$ Contained $2.62 \times 10^{5} \mathrm{IU} / \mathrm{kg}$ of vitamin A, $0.27 \times 10^{5} \mathrm{IU} / \mathrm{kg}$ of vita$\min \mathrm{D}, 0.09 \times 10^{5} \mathrm{IU} / \mathrm{kg}$ of vitamin $\mathrm{E}, 0.36 \% \mathrm{Cl}, 0.31 \% \mathrm{~K}, 4.61 \% \mathrm{Mg}$, $10.34 \% \mathrm{Na}, 3.54 \% \mathrm{P}, 0.47 \% \mathrm{~S}, 583.45 \mathrm{mg} / \mathrm{kg}$ of $\mathrm{Cu}, 67.86 \mathrm{mg} / \mathrm{kg}$ of Co, $12.28 \mathrm{mg} / \mathrm{kg}$ of Se, $6.81 \mathrm{mg} / \mathrm{kg}$ of Mo, $43.68 \mathrm{mg} / \mathrm{kg}$ of I 


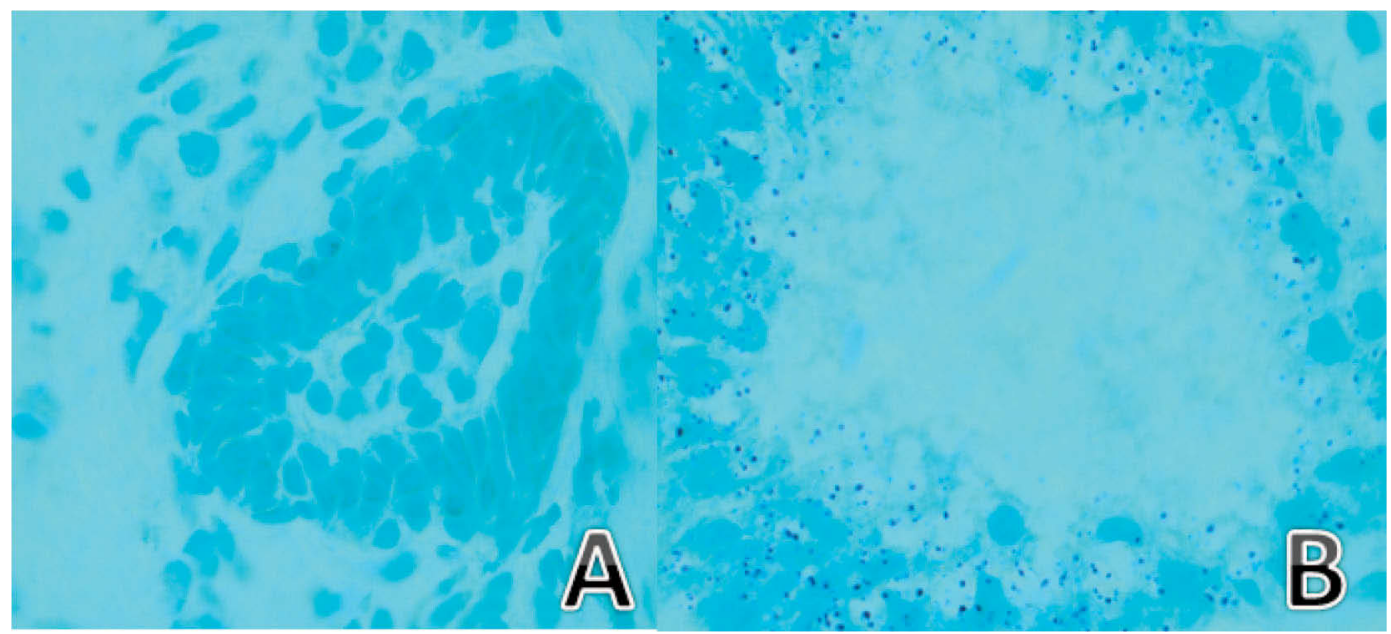

Figure 1. Micrographs (100× magnification) of mammary tissue incubated (A: without; B: with) a solution of succinic dehydrogenase and a tetrazolium compound. The tetrazolium was reduced to formazans, which are water-insoluble tetrazolium. With the addition of hydrogen, the tetrazolium was then converted to purple-blue formazan pigment marking the site of enzyme activity in the mitochondrion. Both tissues were counterstained with methyl green.

magnification (Figure 1). Six fields were randomly selected from each slide by moving the oculars out of focus and the slide on the stage before refocusing to view the field and the mitochondria, which were stained purple, were counted. The total epithelial cells from the corresponding fields were also counted. The mitochondrial numbers from each cow for d 15, 60, 120, and 230 were calculated and used for statistical analysis.

\section{Detection and Quantitation of Apoptotic Cells}

To detect apoptosis, frozen sections of biopsied mammary tissue prepared from each sample were stained for cleaved caspase-3. Two slides per sample were fixed in $4 \%$ para formaldehyde (Sigma-Aldrich, St. Louis, $\mathrm{MO})$ in PBS pH 7.4 at $4^{\circ} \mathrm{C}$ for $15 \mathrm{~min}$. The slides were washed 3 times in PBS for $5 \mathrm{~min}$ per wash and incubated in blocking buffer (5\% normal goat serum in PBS, Sigma-Aldrich) for $1.5 \mathrm{~h}$ at room temperature inside a humid chamber. The negative slide of each sample was incubated with $50 \mu \mathrm{L}$ of incubation buffer consisting of $1 \%$ BSA and $0.3 \%$ Triton X-100 (Fisher Scientific, Pittsburgh, PA) in PBS. The positive slide of each sample was incubated with $50 \mu \mathrm{L}$ of a 1:200 dilution of cleaved caspase-3 (Cell Signaling Technology, Danvers, MA) primary antibody to rabbit in incubation buffer. This primary antibody is predicted to react with bovine based on a $100 \%$ sequence homology with humans. All slides were incubated overnight at $4^{\circ} \mathrm{C}$ in a humid chamber, the following fluorescent antibody steps were done in a darkroom. The slides were incubated in secondary antibody (Alexa Flour 488 Goat anti-rabbit, Invitrogen, Carlsbad, CA) for $2 \mathrm{~h}$ at room temperature, washed twice in PBS for $10 \mathrm{~min}$, and incubated for $5 \mathrm{~min}$ in $0.1 \mu M$ Sytox Orange (Molecular Probes, Grand Island, NY) before mounting. Specimens were imaged using a fluorescent microscope (Leica Microsystems, Buffalo Grove, IL) and digital images were captured using Image Pro5.1 software (Media Cybernetics, Bethesda, MD) for quantitative analysis of cells expressing the caspase- 3 antigen (apoptotic; see Figure 2 for representative digital image). For each slide, 10 pictures of randomly selected fields were photographed at $40 \times$ magnification. From each photo, the apoptotic mammary epithelial cells were counted manually and epithelial cells were counted by the counting tool of Image-Pro 5.1 software (Media Cybernetics). Cleaved caspase-3 apoptotic cells were stained green and normal epithelial cells were stained red. Apoptosis percent was the total number of caspase positive cells per total number of epithelial cells counted multiplied by 100 .

\section{Milk RNA Isolation}

Whole milk for RNA isolation was collected before mammary biopsies on d 15, 60,120, and 230 of lactation. About $40 \mathrm{~mL}$ of milk from each udder half was collected directly into sterile 50-mL RNase-free centrifuge tubes, $4 \mathrm{~mL}$ of which was decanted into $8 \mathrm{~mL}$ of TRIzol LS (Invitrogen). The tubes were shaken for about $15 \mathrm{~s}$ then immediately placed on ice, transferred to the laboratory, and stored at $-80^{\circ} \mathrm{C}$. The isolation procedure proceeded using the manufacturer's recommendations for fat-containing samples. 


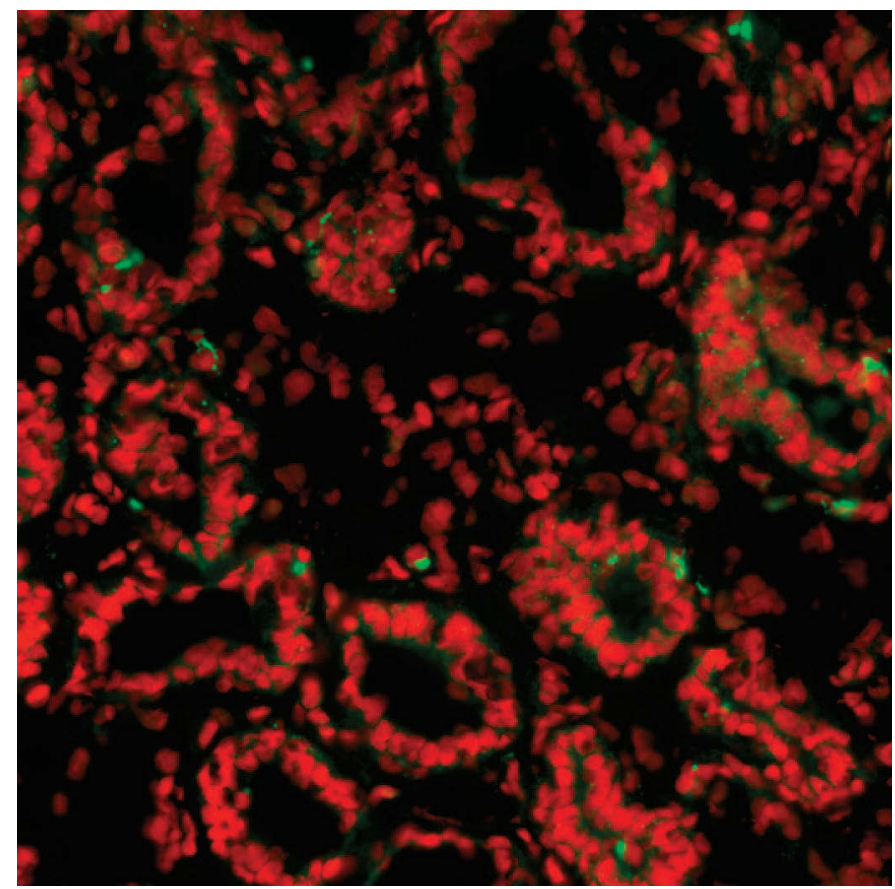

Figure 2. Fluorescent micrograph $(40 \times$ magnification $)$ of lactating alveolus and epithelial cells from once daily milked $(1 \times)$ udder half at d 15 of lactation. Apoptotic cells stained green (caspase-3) and normal epithelial cells red. AC = apoptotic mammary epithelial cell.

\section{cDNA Synthesis}

Prior to cDNA synthesis, RNA was treated with DNase I (amplification grade, Invitrogen) according to the manufacturer's recommendations. iScript cDNA synthesis kit (Bio-Rad Laboratories, Hercules, CA) was used for cDNA synthesis according to the manufacturer's protocol.

\section{Quantitative Real-Time PCR}

Gene sequences used for primer design were obtained from GenBank (NIH, Bethesda, MD). The abundance of mRNA for SOCS-1, SOCS-2, SOCS-3, cytokine-inducible $\mathrm{SH}_{2}$-containing protein $(C I S)$, $\alpha$-LA $(L A L B A)$, and $\beta-\mathrm{CN}$ (CSN2) were analyzed using primer sequences for the bovine genes (Table 2). Quantitative real-time PCR was run on an iCycler IQ RT-PCR detection system (Bio-Rad) in a 96-well format. Quantitative PCR was run on all samples for 6 genes of interest and a housekeeping gene $(R P S 15 A)$. The genes evaluated for selecting the housekeeping genes were $18 S, G A P D H$ (Robinson et al., 2007), HPRT (Goossens et al., 2005), ACTB, UXT, RPS15, RPS9 (Bionaz and Loor, 2007), and PPP1R11 and RPS15A (Piantoni et al., 2008). Gene RPS15A was selected because it showed consistency with all genes of interest. All samples were run in triplicate. Housekeeping gene results from $1 \times$ milk for all animals at a given time point were averaged for a value for which to compare $4 \times$ milk gene expression. For individual genes, the $1 \times$ milk gene expression was used as the reference value for $4 \times$ gene expression to calculate fold change. The resulting gene expression was calculated and analyzed using the $2^{-\Delta \Delta \mathrm{Ct}}$ (cycle threshold) method (Livak and Schmittgen, 2001).

\section{Statistical Analysis}

All statistical analyses were performed using Proc Mixed procedures in SAS (SAS Institute, Cary, NC). For milk yield and composition analyses, data collected from both udder halves from mo 1 to 8 of lactation were used. Data from caspase-3 assay was transformed into Arc-cosine value to meet statistical assumptions for normal data distribution. Statistical analysis of $\Delta \mathrm{Ct}$ (Livak and Schmittgen, 2001) values from quantitative PCR assays included independent variables of biopsy dates, udder halves, and their interaction.

\section{RESULTS}

\section{Milk Yield and Composition}

Increasing the milking frequency for $278 \mathrm{~d}$ of lactation elevated the $4 \times$ udder half milk yield $(P<0.001)$ compared with the $1 \times$ udder half (Figure 3 ). When

Table 2. Primer sequences for bovine suppressors of cytokine signaling (SOCS)-1, -2, and -3, cytokine-inducible $\mathrm{SH}_{2}$-containing protein $(C I S)$, $\alpha$-LA (Lalba), $\beta$-CN (Csn2), and ribosomal protein S15A (RPS15A) ${ }^{1}$

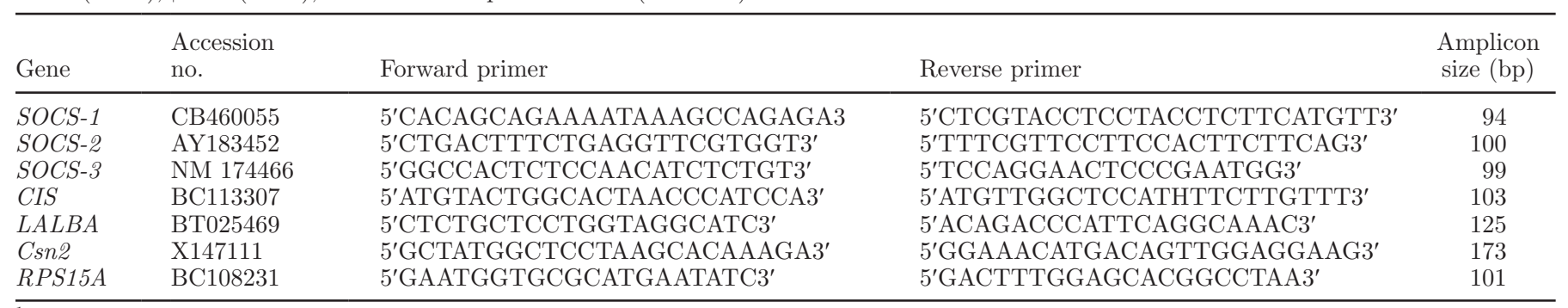

${ }^{1}$ Gene-specific primers were designed based on the available sequences in GenBank (accession numbers indicated). 
Table 3. Effect of increased milking frequency on mean half-udder milk composition for $230 \mathrm{~d}$ of lactation in Holstein dairy cows ${ }^{1}$

\begin{tabular}{lcccc}
\hline Variable $^{2}$ & $1 \times$ & $4 \times$ & SEM & $P$-value \\
\hline Fat, \% & 3.58 & 3.40 & 0.11 & 0.250 \\
Protein, \% & 2.27 & 2.83 & 0.03 & 0.013 \\
Lactose, \% & 4.00 & 4.30 & 0.07 & 0.004 \\
SNF, \% & 7.80 & 8.10 & 0.0 & 0.0006 \\
Fat yield, kg/d & 0.29 & 0.61 & 0.02 & 0.001 \\
Protein yield, kg/d & 0.22 & 0.53 & 0.01 & 0.005 \\
Lactose yield, kg/d & 0.32 & 0.81 & 0.70 & 0.033 \\
SNF, kg/d & 0.70 & 1.11 & 0.06 & 0.0001 \\
\hline
\end{tabular}

${ }^{1} 1 \times, 4 \times=$ mean milk composition once or four times daily milked udder halves, respectively, for $230 \mathrm{~d}$ of lactation. Milk samples from each udder half were collected each week for 8 mo of lactation and analyzed by Arizona Dairy Herd Improvement Association (AZ DHIA).

${ }^{2}$ Milk fat, protein, and lactose were analyzed using AOAC-approved infrared analysis (AOAC International, 2007). Yield of variable $=$ Mean milk yield $\times$ mean composition of variable for $230 \mathrm{~d}$.

averaged over the entire lactation, half-udder milk yield was twice as high in $4 \times$ udders in comparison to $1 \times$ $(19$ vs. $8 \mathrm{~kg} / \mathrm{d})$. Mean $4 \times$ udder half milk production was higher at all stages of lactation compared with $1 \times$ (Figure 3, $P<0.001$ ).

Analysis of milk composition variables revealed that milk protein percent $(P=0.01)$, milk lactose percent $(P=0.004)$, and SNF percent $(P=0.006)$ were also increased in $4 \times$ udders compared with $1 \times$ (Table 3 ). Mean fat percent was not affected by increased milking frequency $(P=0.25)$. The $4 \times$ udders also had higher yields of milk fat $(P=0.001)$, protein $(P=0.005)$, lactose $(P=0.03)$, and $\operatorname{SNF}(P=0.001)$ compared with $1 \times($ Table 3$)$.

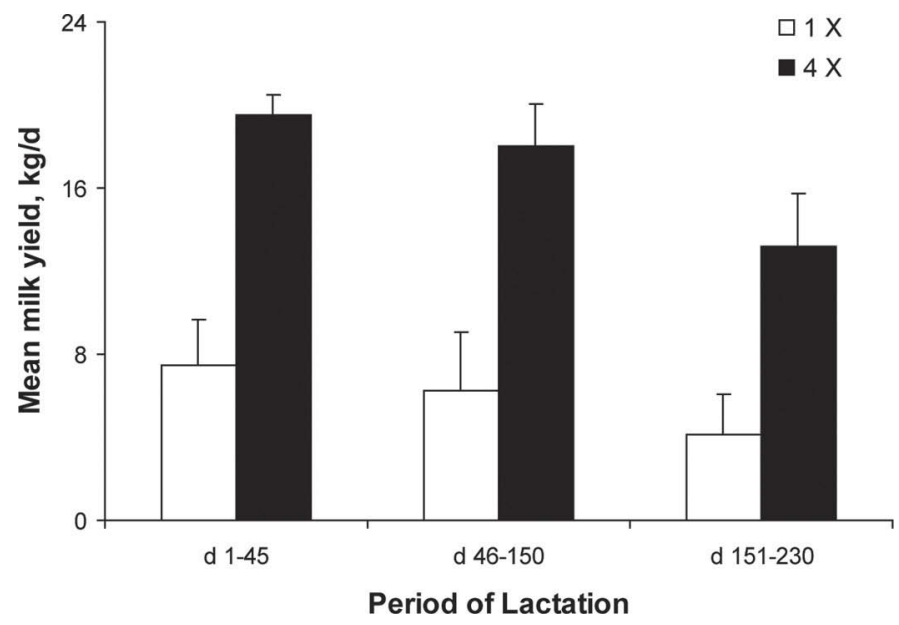

Figure 3. Effect of increased milking frequency on mean half udder milk yield in lactating Holstein dairy cows during 3 periods (1-45, 46-120, and 151-230 d) of lactation. Mean milk yield from the udder halves milked four times a day $(4 \times)$ was increased in all 3 stages of lactation. $1 \times=$ once daily milking. The figure shows the mean \pm SEM, $\mathrm{n}=6 /$ treatment; means differ, $P<0.001$.

\section{Mitochondrial Number}

In situ staining for succinate dehydrogenase has been previously used as a clinical tool to evaluate mitochondrial mass (Hadsell et al., 2011). Analysis of succinate dehydrogenase staining in mammary tissue demonstrated that mitochondrial index [the ratio of mitochondria (counted manually) to the total epithelial cells in the field (counted manually)] was influenced both by time postpartum (Figure $4, P<0.001$ ) and by milking frequency $(P<0.001)$. Average mitochondrial counts were highest at d 15 (27.4) and declined with progression through lactation (Figure 4). Mean mitochondrial counts across lactation for $4 \times(23.6)$ were higher than $1 \times(18.6, P<0.02)$. Mitochondrial counts were higher in $4 \times$ than $1 \times$ udders on $\mathrm{d} 15,60$, and 120 postpartum, but were similar by d 230 .

\section{Mammary Cell Apoptosis}

To determine the effect of stage of lactation and milking frequency on mammary cell apoptosis, tissue sections were stained for cleaved caspase-3. Total numbers of cleaved caspase-3-positive cells per field were highest on d 15 and decreased $(P<0.01)$ with time postpartum, whereas total nuclear counts were affected little by time postpartum. Percent mammary apoptosis was highest at d 15 postpartum and decreased $(P$ $<0.005$ ) with time postpartum (Figure 5). Increased milking frequency had no overall effect $(P=0.67)$ on mammary apoptosis percentage for the entire lactation.

\section{Gene Expression}

To identify potential molecular mechanisms underlying the effect of milking frequency on milk yield, the expression of selected milk protein genes along with the $S O C S$ genes, were measured in RNA isolated from milk at postpartum sampling times. In regard to milking frequency, expression of the $S O C S$ genes were not affected (Table 4). In contrast, both $L A L B A$ and CSN2 were increased by $4 \times$ milking frequency (Table 4 ) from 2 - to 8-fold and 2- to 4-fold, respectively (Figure 6). The higher concentration of mammary epithelial specific genes rules out contamination from somatic cells or dilution due to higher milk yield in $4 \times$ animals.

\section{DISCUSSION}

Among the various determinants of profitability in a dairy herd, lactation persistence is considered as one of the most important parameters (Bar Anan et al., 1985; Stelwagen, 2001). Milk yield in dairy cows can be increased by a variety of means, including improv- 


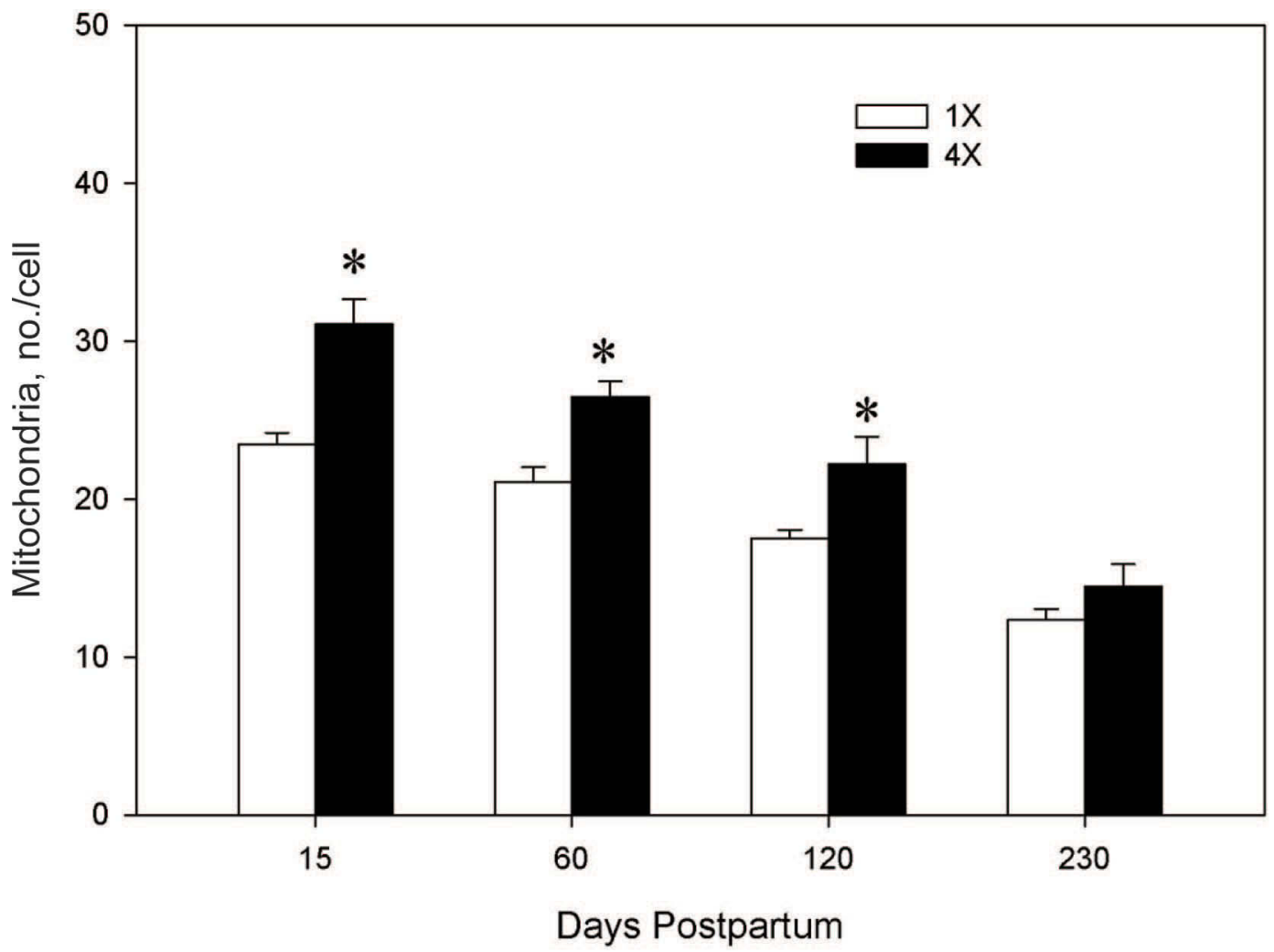

Figure 4. Increased milking frequency increases mean half udder mitochondria per cell [the ratio of mitochondria (counted manually) to the total epithelial cells in the field (counted manually) in lactating Holstein dairy cows]. Increased milking frequency increased mitochondrial cell number $(P<0.001)$. Mitochondria number per cell was also influenced by time postpartum $(P<0.001)$. The figure shows the mean and standard error, $\mathrm{n}=6$ /treatment. Asterisks $(*)$ indicate a significant difference between udder halves milked once $(1 \times)$ and four times per day $(4 \times ; P<0.05)$ at a given time point.

ing the genetic background, environment, hormone treatment, milking, and feeding methods (Bar Peled et al., 1995). Increased milking frequency is one of the most fundamental methods used to improve milk yield (Collier et al., 2010). In our study, a 4-fold difference in milking frequency was expected to produce a larger response than those previously reported, where the differences in frequency were only 2-fold (Barnes et al., 1990). Reduction of milking frequency from $2 \times$ to $1 \times$ has previously been reported to result in diminished milk yields ranging from 7 to $38 \%$ (Davis et al., 1998). Conversely, an increase in milking frequency from $2 \times$ to $4 \times$ produced yield increases of about 10 to $20 \%$ (Hale et al., 2002; Nørgaard et al., 2005). Consistent with these expectations, the mean milk production from the $4 \times$ udder halves was approximately 2 times higher than $1 \times$ udder halves during early, middle, and late lactation, suggesting that this extreme difference in milk frequency produced a more dramatic milk yield difference than previously observed.

The effects of milk frequency on milk composition in the current study are also consistent with previous work. Many of the changes in milk composition from $1 \times$ udder halves are probably related to changes in tight junction permeability (Davis et al., 1999). However, there is also reason to believe that alterations in mammary cell metabolic or biosynthetic activity may also be associated with some of the changes in milk composition. For example, the RNA message content of milk from $4 \times$-milked cows was higher than the concentration of the same RNA from milk of $1 \times$ animals across lactation (Figure 4). In addition, the mitochondria per cell was increased in cows milked $4 \times$. Dairy cows milked $1 \times$ daily have been observed to produce milk with less lactose (Carruthers et al., 1993); the comparison of $1 \times$ with $4 \times$ milk in the present study agrees with this finding. In addition, the fact that $L A L B A$ mRNA is lower in $1 \times$ than $4 \times$ also suggests the possibility that decreased activity of the lactose biosynthesis pathway may also occur with $1 \times$ milking. In support of this, recent microarray studies in cows have demonstrated that genes involved in galactose metabolism are decreased by $1 \times$ versus $2 \times$ milking frequency (Littlejohn et al., 2010). In addition, our recent work on milking frequency in mice 
Table 4. Effect of increased milking frequency on mean half-udder SOCS (1-3) and CIS gene expressions in RNA extracted from milk of lactating Holstein dairy cows ${ }^{1}$

\begin{tabular}{|c|c|c|c|c|c|c|}
\hline \multirow{2}{*}{$\begin{array}{l}\text { Gene of } \\
\text { interest }\end{array}$} & \multirow[b]{2}{*}{$1 \times$} & \multirow[b]{2}{*}{$4 \times$} & \multirow[b]{2}{*}{ SEM } & \multicolumn{3}{|c|}{$P$-value } \\
\hline & & & & Treatment & Time & Treatment $\times$ time \\
\hline SOCS 1 & 4.1 & 3.6 & 0.4 & 0.31 & 0.03 & 0.57 \\
\hline SOCS2 & 9.4 & 10.8 & 0.9 & 0.14 & 0.0001 & 0.09 \\
\hline SOCS3 & 5.1 & 4.3 & 0.4 & 0.08 & $<0.0001$ & 0.96 \\
\hline$C I S$ & 7.8 & 8.7 & 0.6 & 0.26 & 0.0001 & 0.24 \\
\hline$\alpha-L A$ & 6.0 & 4.4 & 0.5 & 0.04 & $<0.0001$ & 0.79 \\
\hline$\beta-\mathrm{CN}$ & 1.3 & 0.1 & 0.8 & 0.15 & 0.04 & 0.94 \\
\hline
\end{tabular}

${ }^{1} 1 \times, 4 \times=$ mean $\Delta \mathrm{Ct}$ values for once and four times daily milked udder half milk, respectively. $\Delta \mathrm{Ct}=\mathrm{CtGOI}$ - CtRPS15A, (where Ct $=$ cycle threshold, GOI = gene of interest, and RPS15A = housekeeping gene). Half udders $(\mathrm{n}=12)$ were sampled at $\mathrm{d} 15,60,120$ and $230 \mathrm{~d}$ of lactation. Gene expression was evaluated by realtime, reverse transcription-PCR from $1 \times$ and $4 \times$ udder half milk sample pools. Genes $=$ suppressor of cytokine signaling $(S O C S)$; cytokine inducible $\mathrm{SH} 2$ containing protein $(C I S)$.

also supports the conclusion that changes in galactose metabolism and lactose biosynthesis play a role in mediating the effects of milking frequency on lactation in that species (Hadsell et al., 2012). We cannot address the question of whether or not additional alveolar units are in production in $4 \times$ - versus $1 \times$-milked cows and we also cannot address whether or not only a subset of mammary epithelial cells have higher synthetic activity in $4 \times$-milked cows. With regard to milk protein, our results are also consistent with previous work demonstrating that milk from $1 \times$ cows had lower percentage of protein than that from $2 \times$ cows (Knight and Dewhurst, 1994). Likewise, milk from $1 \times$ udder halves had lower protein than $4 \times$ udder halves.

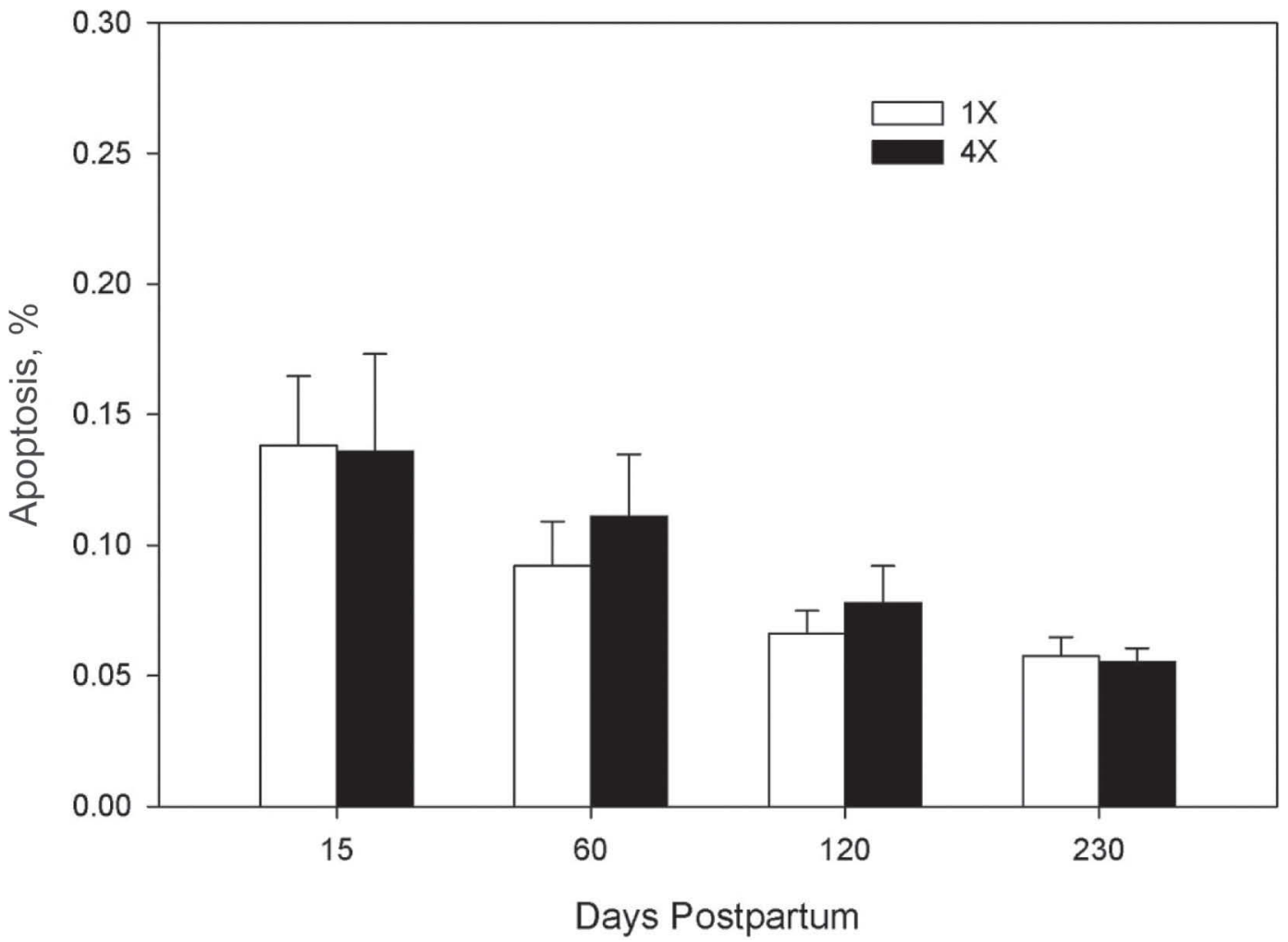

Figure 5. Effect of stage of lactation and milking frequency on apoptosis. Frozen sections of mammary tissue from once $(1 \times)$ or four times $(4 \times)$ daily milked udders were stained for cleaved caspase-3 and counterstained with the nuclear dye, Sytox orange. Apoptosis $\%=($ total number of caspase positive cells/total number of epithelial cells counted $) \times 100$. Apoptosis decreases with time postpartum $(P<0.01)$ and apoptosis rates on d 15 of lactation were higher than rates at d 230 of lactation for both $1 \times$ - and $4 \times$-treated animals $(P<0.02)$, but is not influenced by milking frequency. Each bar represents the mean and $\mathrm{SE}, \mathrm{n}=6$ /treatment. 


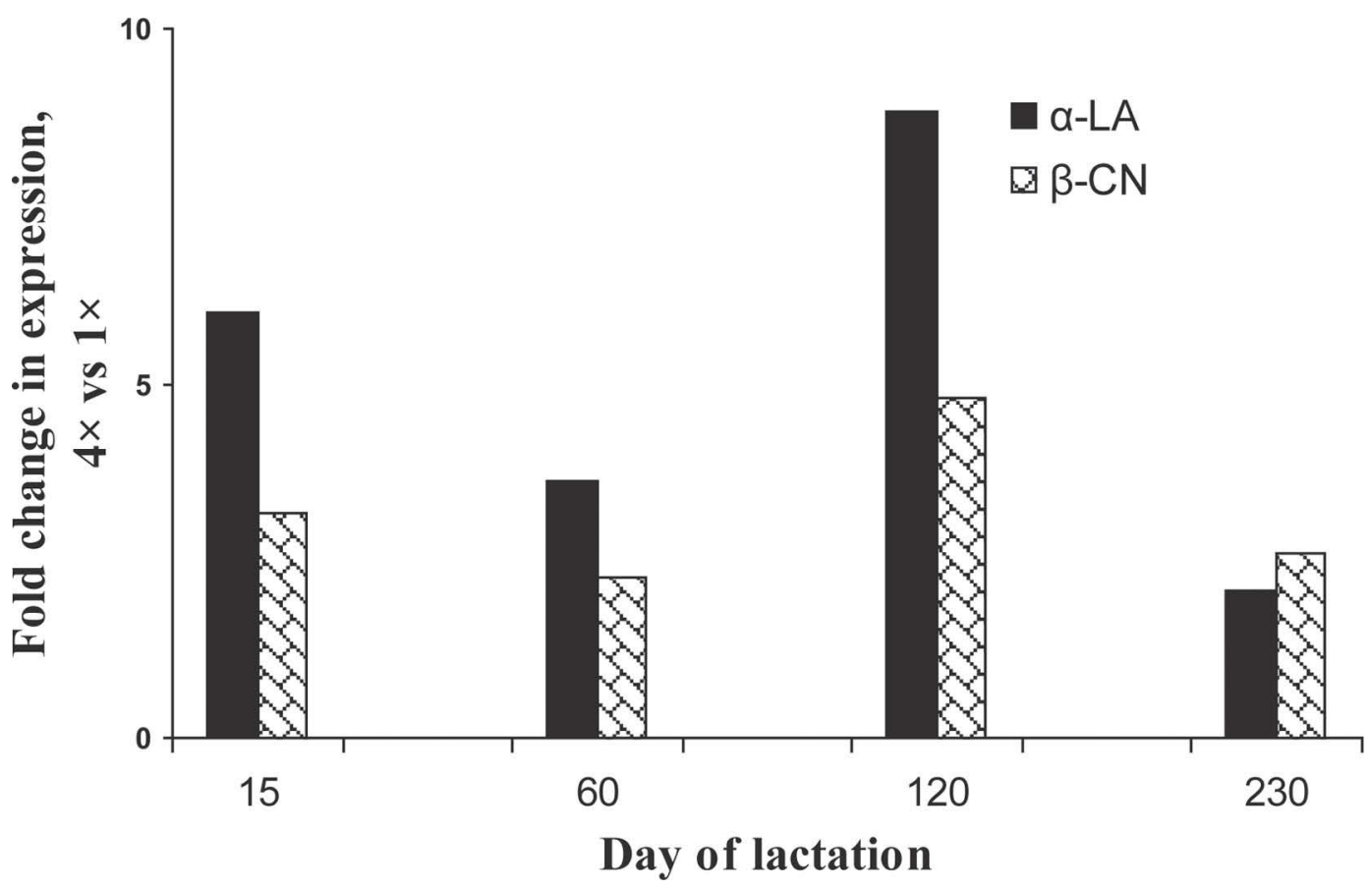

Figure 6. Fold changes in gene expression in RNA extracted from milk comparing the four times $(4 \times)$ to the once daily $(1 \times)$ milked udder half. Half-udders $(\mathrm{n}=12)$ were used to compare physiological state of the mammary gland with samples taken at $\mathrm{d} 15,60,120$, and $230 \mathrm{~d}$ of lactation. Gene expression was evaluated by quantitative real-time, reverse transcription-PCR using $1 \times$ and $4 \times$ udder half milk sample pools from each udder half. Fold changes in expression were determined by $2^{-\Delta \Delta \mathrm{Ct}}$ (cycle threshold) calculations. Pooled SEM for $\alpha$-LA and $\beta$-CN $=$ 1.3 and 0.9 , respectively.

Most aspects of milk synthesis are dependent upon the mitochondrion, which is the major organelle for production of ATP (Huang and Keenan, 1971). Despite this understanding, the relationship between mitochondria number and milk production has been most intensively studied in species other than the cow. In the mouse, mitochondrial numbers increase dramatically during lactogenesis (Rosano et al., 1976). In addition, work in the guinea pig has demonstrated that oxidative phosphorylation activity of the mitochondria is increased with the onset of lactation (Nelson et al., 1962). Our recent work in the lactating mouse found that both ATP synthesis activity and the number of mitochondria per cell are coordinately increased with the potential for milk production during early lactation, and these markers decline with progression into late lactation (Hadsell et al., 2011). Increased milk production is usually accompanied by mitochondrial proliferation and higher rates of oxidative phosphorylation because of the high energy demand of lactation. In the present study, the fact that mitochondrial numbers are highest during the early postpartum period and decline with days postpartum agrees with previous studies in mice (Hadsell et al., 2011). This data supports the conclusion that mammary mitochondrial number declines with progression through lactation and that increased milking frequency influences mammary cell mitochondrial turnover, allowing for higher numbers of mitochondria to be maintained. In addition, the fact that higher mitochondrial number occurred in $4 \times$ udders agrees with recent observations in mice under varied nursing frequencies (Hadsell et al., 2011). Data from these results warrant the need for further studies on the role of mammary cell mitochondria in determining the effect of milking frequency on milk yield.

The SOCS proteins (SOCS-1, -2 , and -3 and CIS) act by inhibiting cytokine and growth factor signaling pathways (Ueki et al., 2004) and are known to regulate signaling by cytokines such as prolactin and growth hormone (Collier et al., 2002). Expression of these genes has been shown to be modulated by milking frequency in the bovine mammary gland (Wall et al., 2005). In the present study, however, SOCS gene expression was not influenced by milking frequency. A possible explanation for this is that the analysis was done on RNA prepared from milk rather than from mammary biopsies. Because of differences in cellular contribution to a biopsy sample in comparison to a milk sample, it is not unreasonable to think that genes with expression patterns that are not mammary cell-specific would differ between these 2 approaches. In other words, the $S O C S$ gene expression of milk somatic cells may cause 
too much variance to detect changes in mammary epithelial gene expression in RNA samples prepared from milk. Conversely, the response of $L A L B A$ to milking frequency was similar between the milk RNA analysis in the current study and that observed previously in biopsy specimens (Wall et al., 2006). This may be because $L A L B A$ is a highly abundant mammary cellspecific mRNA. These results, therefore, do not provide definitive information regarding changes in SOCS gene within the mammary epithelial cell and the response of lactation to milking frequency.

Mammary epithelial cell apoptosis is known to vary significantly with stage of lactation. In the mouse, previous work has demonstrated that apoptosis is relatively high during the first few days of lactation and then declines as lactation progresses through the first 2 wk (Hadsell et al., 2006). With prolonged lactation in the mouse, mammary epithelial cell apoptosis increases relative to levels present during mid lactation (Hadsell et al., 2005, 2006). The bovine appears to differ from the mouse because although apoptosis is highest during early lactation, it decreases and remains low at the end of lactation (Nørgaard et al., 2005). In the current study, apoptosis was highest at d 15 postpartum and continually decreased with time postpartum. With regard to nursing frequency, previous work in cows has demonstrated that percent apoptosis of mammary epithelial cells was similar between glands milked at different frequencies (Nørgaard et al., 2005; Wall et al., 2006). In sheep, however, reduced nursing frequency led to increased apoptosis (Li et al., 1999). A greater number of epithelial cells per secretory alveolus was detected in dairy cows milked $4 \times$ (Hillerton et al., 1990), which may account for the reduced apoptosis percentages in the $4 \times$ udder half in the present study. In addition, our recent work in a mouse model of prolonged lactation observed that mammary apoptosis was similar among ad libitum nursed dams and dams with a reduced nursing frequency (Hadsell et al., 2008). These results support the conclusion that changes in mammary epithelial cell death do not necessarily underlie the effects of milking frequency on milk yield.

In summary, previous studies demonstrate that extreme differences in milking frequency are associated with significant changes in mammary cell mitochondria, as well as in the expression of milk protein genes and milk composition. However, we did not detect a difference in mammary epithelial cell apoptosis or SOCS gene expression associated with these extreme differences in milk yield. Small animal numbers and somatic cell content of milk used for gene expression analysis may have contributed to our inability to find differences in these 2 endpoints. Further work on the role of mitochondrial biogenesis and function are necessary to fully understand the significance of these changes to milk production and lactation persistence.

\section{REFERENCES}

Annen, E. L., P. C. Gentry, R. Sprissler, D. L. Hadsell, A. V. Capuco, and R. J. Collier. 2005. Effects of continuous milking (CM) and bovine somatotropin (bst) on mammary gene expression in primiparous cows . J. Dairy Sci. 83:364-365. (Abstr.)

AOAC International. 2007. Official Methods of Analysis. 18th ed. AOAC Int., Arlington, VA.

Auldist, M. J., and C. G. Prosser. 1998. Differential effects of shortterm-once daily milking on milk yield, milk composition and concentrations of selected blood metabolites in cows with low or high pasture intake. Proc. N.Z. Soc. Anim. Prod. 38:41-43.

Bar-Anan, R., M. Ron, and G. R. Wiggans. 1985. Associations among milk yield, yield persistency, conception, and culling of Israeli Holstein dairy cattle. J. Dairy Sci. 68:382-386.

Bar-Peled, U., E. Maltz, I. Brukental, Y. Folman, Y. Kali, H. Gacitura, and A. R. Lehrer. 1995. Relationship between frequent milking or suckling in early lactation and milk production of high producing dairy cows. J. Dairy Sci. 78:2726-2736.

Barnes, M. A., R. E. Pearson, and A. J. Lukes-Wilson. 1990. Effects of milking frequency and selection for milk yield on productive efficiency of Holstein cows. J. Dairy Sci. 73:1603-1611.

Bauman, D. E., and R. G. Vernon. 1993. Effects of exogenous bovine somatotropin on lactation. Annu. Rev. Nutr. 13:437-461.

Baumgard, L. H., B. A. Corl, D. A. Dwyer, A. Saebo, and D. E. Bauman. 2000. Identification of the conjugated linoleic acid isomer that inhibits milk fat synthesis. Am. J. Physiol. Regul. Integr. Comp. Physiol. 278:R179-R184.

Bionaz, M., and J. J. Loor. 2007. Identification of reference genes for quantitative real-time PCR in the bovine mammary gland during the lactation cycle. Physiol. Genomics 29:312-319.

Boutinaud, M., C. Rousseau, D. H. Keisler, and H. Jammes. 2003. Growth hormone and milking frequency act differently on goat mammary gland in late lactation. J. Dairy Sci. 86:509-520.

Carruthers, V. R., S. R. Davis, A. M. Bryant, H. V. Henderson, C. A. Morris, and P. A. Copeman. 1993. Response of Jersey and Friesian cows to once a day milking and prediction of response based on udder characteristics and milk composition. J. Dairy Res. 60:1-11.

Collier, R. J., J. C. Byatt, M. F. McGrath, P. J. Eppard, J. L. Vicini, and C. M. Steining. 2002. Effect of growth factors and hormones on mammogenesis and lactogenesis. J. Dairy Sci. 85(Suppl. 1):53 (Abstr.).

Collier, R. J., D. Romagnolo, and L. H. Baumgard. 2010. Lactation (f) galactopoiesis/seasonal effects. Pages 35-46 in Encyclopedia of Dairy Sciences. Rev. H. Roginski, J. W. Fuquay and P. F. Fox, ed. Academic Press, New York, NY.

Davis, S. R., V. C. Farr, P. J. A. Copeman, V. R. Carruthers, C. H. Knight, and K. Stelwagen. 1998. Partitioning of milk accumulation between cisternal and alveolar compartments of the bovine udder: Relationship to production loss on once-daily milking. J. Dairy Res. 65:1-8.

Davis, S. R., V. C. Farr, and K. Stelwagen. 1999. Regulation of yield loss and milk composition during once-daily milking: A review. Livest. Prod. Sci. 59:77-94.

Erdman, R. A., and M. Varner. 1995. Fixed yield responses to increased milking frequency. J. Dairy Sci. 78:1199-1203.

Farr, V. C., K. Stelwagen, L. R. Cate, A. J. Molenaar, and T. B. McFadden. 1996. An improved method for the routine biopsy of bovine mammary tissue. J. Dairy Sci. 79:543-549.

Goossens, K., M. Van Poucke, A. Van Soom, J. Vandesompele, A. Van Zevern, and L. J. Peelman. 2005. Selection of reference genes for quantitative real-time PCR in bovine preimplantation embryos. BMC Dev. Biol. 5:27-35.

Hadsell, D. L., W. Olea, and L. W. Rottman. 2012. Nursing frequency alters circadian patterns of mammary gene expression in lactating mice. J. Dairy Sci. 95:55.(Abstr.) 
Hadsell, D. L., W. Olea, D. Torres, J. George, and R. J. Collier. 2008. Reduced nursing frequency during prolonged lactation in the mouse decreases milk production and increases mammary expression of tryptophan hydroxylase 1 (TPH1), but does not accelerate mammary remodeling. J. Dairy Sci. 91(E-Suppl. 1):440. (Abstr.)

Hadsell, D. L., O. W. Olea, J. Wei, M. L. Fiorotto, R. K. Matsunami, D. A. Engler, and R. J. Collier. 2011. Developmental regulation of mitochondrial biogenesis and function in the mouse mammary gland during a prolonged lactation cycle. Physiol. Genomics $43: 271-285$.

Hadsell, D. L., D. Torres, J. George, A. V. Capuco, S. E. Ellis, and M. L. Fiorotto. 2006. Changes in secretory cell turnover and mitochondrial oxidative damage in the mouse mammary gland during a single prolonged lactation cycle suggest the possibility of accelerated cellular aging. Exp. Gerontol. 41:271-281.

Hadsell, D. L., D. T. Torres, N. A. Lawrence, J. George, A. F. Parlow, A. V. Lee, and M. L. Fiorotto. 2005. Overexpression of des (1-3) insulin-like growth factor 1 in the mammary glands of transgenic mice delays the loss of milk production with prolonged lactation. Biol. Reprod. 73:1116-1125.

Hale, S., M. Varner, R. Erdman, and A. V. Capuco. 2002. Strategies for increasing herd milk production through more frequent milking. Maryland Dairy Talk 5:1-2.

Hale, S. A., A. V. Capuco, and R. A. Erdman. 2003. Milk yield and mammary growth effects due to increased milking frequency during early lactation. J. Dairy Sci. 86:2061-2071.

Harding, L. G., and F. R. Harding. 1990. Once-daily milking throughout lactation. Pages 85-87 in Dairy Farming Annual. Massey University, Palmerston North, New Zealand.

Hillerton, J. E., C. H. Knight, A. Turvey, S. D. Wheatly, and C. J. Wilde. 1990. Milk yield and mammary function in dairy cows milked four times daily. J. Dairy Res. 57:285-294.

Huang, C. M., and T. W. Keenan. 1971. Membranes of mammary gland. Bovine mammary mitochondria. J. Dairy Sci. 54:13951405 .

Knight, C. H., and R. J. Dewhurst. 1994. Once daily milking of dairy cows: Relationship between yield loss and cisternal milk storage. J. Dairy Res. 61:441-449.

Knight, C. H., P. A. Fowler, and C. J. Wilde. 1990. Galactopoietic and mammogenic effects of long-term treatment with bovine growth hormone and thrice daily milking in goats. J. Endocrinol. 127:129-138

Li, P., P. S. Rudland, D. G. Fernig, L. M. B. Finch, and C. J. Wilde 1999. Modulation of mammary development and programmed cell death by the frequency of milk removal in lactating goats. J. Physiol. 519:885-900.

Littlejohn, M. D., C. G. Walker, H. E. Ward, K. B. Lehnert, R. G. Snell, G. A. Verkeerk, D. A. Clark, and S. R. Davis. 2010. Effects of reduced frequency of milk removal on gene expression in the bovine mammary gland. Physiol. Genomics 41:21-32.

Livak, K. J., and T. D. Schmittgen. 2001. Analysis of relative gene expression data using real- time quantitative PCR and the $2^{-\Delta \Delta \mathrm{Ct}}$ method. Methods 25:402-408.

Nelson, W. L., R. A. Butow, and E. I. Ciaccio. 1962. Oxidative phosphorylation in guinea pig mammary gland mitochondria during various functional states. Arch. Biochem. Biophys. 96:500-505.

Nørgaard, J., A. Sorensen, M. T. Sorensen, J. B. Andersen, and K. Sejrsen. 2005. Mammary cell turnover and enzyme activity in dairy cows: Effects of milking frequency and diet energy density. J. Dairy Sci. 88:975-982.

Piantoni, P., M. Bionaz, D. E. Graugnard, K. M. Daniels, R. M. Akers, and J. J. Loor. 2008. Identification of internal control genes for quantitative polymerase chain reaction in mammary tissue of lactating cows receiving lipid supplements. J. Nutr. 71:112-119.

Robinson, T. L., I. A. Sutherland, and J. Sutherland. 2007. Validation of candidate bovine reference genes for use with real-time PCR Vet. Immunol. Immunopathol. 115:160-165.

Rosano, T. G., S. K. Lee, and D. H. Jones. 1976. Developmental changes in mitochondria during the transition into lactation in the mouse mammary gland, II. Membrane marker enzymes and membrane ultrastructure. J. Cell Biol. 69:581-588.

Stelwagen, K. 2001. Effect of milking frequency on mammary functioning and shape of the lactation curve. J. Dairy Sci. 84(E. Suppl.):E204-E211.

Travers, M. T., M. C. Barber, E. Tonner, L. Quarrie, C. J. Wilde, and D. J. Flint. 1996. The role of prolactin and growth hormone in the regulation of casein gene expression and mammary cell survival: relationships to milk synthesis and secretion. Endocrinology $137: 1530-1539$

Ueki, K., T. Kondo, and C. R. Kahn. 2004. Suppressor of cytokine signaling 1 (SOCS-1) and SOCS-3 cause insulin resistance through inhibition of tyrosine phosphorylation of insulin receptor substrate proteins by discrete mechanisms. Mol. Cell. Biol. 24:5434-5446.

Wall, E. H., T. L. Auchtung-Montgomery, G. E. Dahl, and T. B. McFadden. 2005. Short communication: Short-day photoperiod during the dry period decreases expression of suppressors of cytokine signaling in mammary gland of dairy cows. J. Dairy Sci. $88: 3145-3148$

Wall, E. H., H. M. Crawford, S. E. Ellis, G. E. Dahl, and T. B. McFadden. 2006. Mammary response to exogenous prolactin or frequent milking during early lactation in dairy cows. J. Dairy Sci. 89:4640-4648

Wilde, C. J., A. J. Henderson, C. H. Knight, D. R. Blatchford, A. Faulkner, and R. G. Vernon. 1987. Effects of long-term thrice-daily milking on mammary enzyme activity, cell population and milk yield in the goat. J. Anim. Sci. 64:533-539. 